Nordic Journal of Comparative and

International Education (NJCIE)

NJCIE 2021, Vol. 5(1), 1-16

$\underline{\text { http://doi.org/10.7577/njcie.3825 }}$

\title{
Comparing Early Childhood Teacher Education in the Subjects of Language Learning and Early Literacy in Denmark and Norway
}

\author{
Liv Gjems \\ University of South-Eastern Norway \\ Ida Kornerup \\ University College Copenhagen (KP) \\ Bente Vatne ${ }^{1}$ \\ Volda University College \\ Vibeke Schrøder \\ University College Copenhagen (KP) \\ Copyright the authors \\ Peer-reviewed article; received 13 April 2020; accepted 29 December 2020
}

\begin{abstract}
Few studies highlight the content of early childhood teacher education (ECTE) and examine the quality of knowledge acquired by future early childhood teachers. The current study concerns two questions. The first explores the goals of the national curricula in Danish and Norwegian ECTE concerning children's language learning and early literacy. The second explores how satisfied Danish and Norwegian student teachers are with their own subjective learning outcomes related to the same themes. To answer the first question, data were collected through document analysis of the two countries' national curricula. To answer the second question, data were collected through a survey handed out to student teachers in both countries at the end of their education. The survey contained questions about factual, procedural, and meta-knowledge areas. The survey participants comprised 199 Norwegian student teachers from three University Colleges and 90 Danish student teachers from three separate campuses at one University College. This study reveals that the Norwegian student teachers evaluated their subjective learning outcomes in the fields of language learning and early literacy more highly than Danish student teachers. Our research points to the fact that, compared to the Norwegian ECTE, the breadth of subjects in the Danish ECTE bachelor program tends to give lower subjective learning outcomes in these knowledge areas.
\end{abstract}

Keywords: language learning, early literacy, factual, procedural and meta-knowledge

\section{Introduction}

This study aims to explore and discuss the field of children's language learning and early literacy in Early Childhood Teacher Education (ECTE) in Denmark and Norway. These two countries have been chosen because they share a similar ideology concerning early childhood education, with the main emphasis on play and care as modes of learning. Kindergarten teachers

\footnotetext{
${ }^{1}$ Corresponding author: bente.vatne@ hivolda.no
} 
in both countries must have a bachelor's degree, and the childcare rate in both Denmark and Norway is very high (Report of the Working Group on Early Childhood Education and Care, 2014). It could be both interesting and relevant to put into perspective our study of early literacy in the Nordic ECTE into a European educational perspective. However, to retain a limited focus, we have chosen not to include a European education perspective in the article. Gjems and Sheridan (2015) conducted a comparative study of student preschool teachers' conceptions of the knowledge that they claimed to have acquired about children's early literacy throughout their bachelor's education in Norway and Sweden. This study was the starting point for developing relevant questions for our document analysis and survey.

Early childhood is a period of rapid learning and development, and early childhood education and care (ECEC) plays a key role in enabling children to read and write later in life. International research supports the notion that early childhood teachers' professional development has an impact on the quality of early childhood programs and consequently on children's educational, social, and emotional developmental outcomes (Barnett, 2003; Early et al., 2006; Sylva et al., 2010; Manning et al., 2017).

Given the complexity and multidimensionality inherent in children's learning and developmental outcomes, some researchers have, according to Manning et al. (2018), identified several outcome categories (e.g. mathematics and numeracy skills, language, and literacy) with which to measure teaching quality. However, studies often use the number of years of professional education and degree obtained as quality indicators (Early et al., 2007). Few studies highlight the content of early childhood teacher education (ECTE) and examine the quality of knowledge acquired by future early childhood teachers (Cunningham et al., 2009). This study focuses on the content of ECTE, specifically as it relates to children's language learning and early literacy.

Literacy is high on the agenda of international organizations such as the UN, the World Bank, and the World Health Organization, and is considered a key element in questions involving human rights issues. UNESCO (2013) defines literacy as a fundamental human right and highlights the fact that access to education is inextricably linked to literacy. Literacy development starts as soon as a child is born, and the preschool years are crucial in learning to read and write (Dickinson \& Porche, 2011).

We ask two research questions: 1) What are the goals of the national curricula in Danish and Norwegian ECTE concerning children's language learning and early literacy? 2) How satisfied are Danish and Norwegian student teachers with their own subjective learning outcomes related to children's language learning and early literacy?

To answer the first research question, data were collected through document analysis of the two countries' national curricula. To answer the second research question, data were collected through a survey handed out to student teachers in both countries. The survey contains questions about factual, procedural, and meta-knowledge areas (Shulman, 2004). In this part of the study, the student teachers evaluated their satisfaction with their own subjective learning outcomes. This study focuses on children's general language learning. However, we asked the student teachers to identify the challenges that children with Danish and Norwegian as a second language may face in their interactions with peers. Students in both countries expressed low subjective learning outcomes in this area. Since the multilanguage subject has received little 
attention in the national plans of both Denmark and Norway, we focused on the language experiences of importance for all children.

\section{The Danish and Norwegian Contexts}

A major educational concern of politicians worldwide is to develop programs that enable future teachers to acquire enough knowledge and skills to succeed in their pedagogical work after graduation. Acquiring such knowledge and skills depends very much on the structure and content of the program, which in turn will influence how newly qualified teachers perceive and perform their roles. ECTE is based on a standardized bachelor program in both Denmark and Norway. The national curricula in both countries provide a strong framework for Early Childhood Teacher Education. One difference between the two programs concerns the academic and practical scope of teacher education. In Norway, student teachers who want to work in the field of ECEC take a three-year program (180 ECTS) aimed specifically at teaching younger children (1-6 years). Danish student teachers pursue a three-and-a-half-year general education program (210 ECTS) that covers a broader field of pedagogical and social pedagogical work with both children and adults.

Another interesting difference is how the practice placement periods are organized. In Norway, this constitutes an integrated part of the program and student teachers are supervised by teacher educators. As an integrated part of the curriculum, it must cover all subjects during the three years of education. The practice placement is a minimum of 100 days' distributed all through the three-year program. As an integrated part of the ECTE curriculum, it does not carry any ECTS credits out of the total 180 ECTS credits. In Denmark, the practice placement is organized through three periods. The first period is 47 days (14 ECTS) in the first year then followed by paid practice placement periods in the third and sixth semesters, each accounting for 30 ECTS credits. As members of staff in ECEC institutions, student teachers are paid employees; they receive some guidance from the ECEC teachers but are to a large extent educationally detached from the university college during these two periods. Practice placement accounts for 74 ECTS credits out of the total 210 ECTS credits in the Danish ECTE program.

The last two paid placement periods and the status as employees and not students draw attention to a significant difference between the organization of the Danish and the Norwegian ECTE. Looking at the total time spent at the ECTE program at the university/college and under the ECTE responsibility in the two compared countries, it leaves the Danish students with an ECTE total of 150 ECTS points compared to the Norwegian ECTE total of 180 ECTE points. This fact might influence the academic content of ECTE in the two compared countries in the way that the Norwegian ECTE is both more specifically targeted ECEC but also academically stronger than the Danish ECTE. It also might influence the result of the student's subjective satisfaction with the academic content of the ECTE.

\section{The Social Pedagogical Perspective}

Social pedagogical perspectives, which grew in popularity during the seventies, have greatly influenced national curriculums. This trend is often referred to as the "Nordic approach to Early Childhood Education' (Einarsdottir, 2013; Roth, 2014; Bennet, 2010). In recent years, both 
countries have seen an increasing political focus on aspects of children's learning that has had an impact on curriculums in ECTE and ECEC in general (Roth, 2014).

Bennett (2010) described the social pedagogical approach to ECEC, as opposed to the preprimary approach. While the pre-primary approach emphasizes academic learning intending to prepare the child for school, the social pedagogical approach focuses on the development of children's social skills, aiming to empower children as active, autonomous participants. Both perspectives regard play as young children's basic learning activity, but while the pre-primary approach puts more emphasis on teacher-led pedagogy, social pedagogy gives children greater freedom to choose which activities they want to participate in.

While the social pedagogical perspective has also led to a comprehensive, holistic concept of learning - the aim of which is to provide coherence between different topics and different aspects of learning theory - this may take place at the expense of a more in-depth understanding of each topic (Einarsdottir, 2013). Thus, there are concerns about whether the social pedagogical approach to learning has reduced student teachers' ability to acquire in-depth content knowledge of core topics within the subjects of language learning and social development, and whether they gain sufficient theoretical knowledge of specific methods to implement them successfully in their practical pedagogical work. Ohlson (2011) presented indepth learning as a comprehensive cognitive change that carries three key elements, the first of which, creativity, involves breaking with ordinary ways of thinking. The second element, transfer of learning, involves adapting knowledge and actions to new contexts. The third element involves changing assumptions and the understandings one has about the environment and knowledge. Achieving in-depth learning in kindergarten teacher education can be a challenge when the social pedagogical ideal dominates.

\section{Theoretical Background}

\section{Types of Knowledge}

Zeichner (2006) cited several researchers who studied student teachers and analyzed how their knowledge, skills, and dispositions are influenced by their teacher education programs. The national curriculum provides a framework for the knowledge and ideology that ECTE students encounter through their program descriptions and teachers. According to Shulman (2004), future teachers, at all educational levels, are expected to acquire from their teacher education a minimum level in three types of knowledge:

1. First, they need factual knowledge, i.e. theoretical and research-based knowledge about subject fields and processes covering children's development and learning, also called "knowing what".

2. Secondly, they must have knowledge about procedures for how to apply factual knowledge in pedagogical work with children, called "knowing how", or procedural knowledge.

3. Thirdly, they must understand why they need such factual and procedural knowledge, called "knowing why", which is also called meta-knowledge.

A key skill for any teacher's professional work is her/his ability to recognize what a child can and cannot master. Teachers must possess knowledge of the specific cognitive requirements 
in an educational field, in addition to pedagogical knowledge about typical ways to adapt their teaching to optimize learning in a special field (Blömeke et al., 2008; Sheridan et al., 2011). According to research by Hattie (2009), any teacher education must ensure that teachers have both subject knowledge and knowledge of how to teach if they are to contribute successfully to children's learning and mastery of different skills. It is important that ECTE students can reflect upon - and give reasons for-intentions, choices, and actions. This is stated explicitly in the Norwegian National Curriculum for ECTE (Ministry of Education and Research, 2012), and in the Danish National Curriculum (The Ministry of Higher Education and Science, 2007).

\section{The Knowledge Area of Children's Language Learning and Early Literacy}

To learn the many facets of language, children should be in a favorable learning environment that supports them in saying what they mean, think, wish, and feel, and which ensures that they engage in close social interactions with both teachers and peers (Dickinson et al., 2003; Neuman \& Cunningham, 2008). Future teachers must learn and understand the content of the subjects in the curriculum, and they must learn how to act based on this knowledge. Consequently, early childhood teachers must have a thorough knowledge of how children learn a language, as well as the role language plays as a tool in different aspects of children's learning. Furthermore, they must learn how to facilitate a stimulating language milieu, and how they can support language learning for children at different levels of competence and ability (Neuman \& Cunningham, 2009; Sandvik et al., 2014).

Early literacy refers to language learning from birth to age eight (Barton, 2007; Snow et al., 2001) and includes children's learning of what words and concepts represent. Both early literacy and language learning are broad and complex fields of research. Children must learn the meaning of words and how they can combine words into sentences. In addition, they must learn how morphemes can change the meaning and function of words. This includes learning that signs and symbols are related to certain types of content. The most extensive language learning in a person's life occurs during childhood, and research has revealed that children who do not acquire a functional level of language in their early years will struggle with languagebased learning throughout most of their life (among others Neuman \& Marulis, 2010; Snow, 2000). Learning words and communicating with others through words are of crucial importance in many areas, as vocabulary boosts the acquisition of knowledge, and language functions as the key tool for social interaction and resolving problems. In addition to children's ability to learn more about their environment, vocabulary is crucially significant for children's participation in conversations and play with their peers. In both breadth and depth, children's knowledge of words is essential to their learning to read and write in school (August et al., 2005; Aukrust \& Rydland, 2009; Hjetland et al., 2017). Accordingly, early childhood education teachers must know how children learn a language, particularly how they acquire new words and their associated concepts (Nelson, 2009).

\section{Methodology}

This study used a sequential mixed-methods approach consisting of document analysis and a survey (Creswell \& Creswell, 2018). The advantage of using mixed methods is that the result 
of one method informs the other (Creswell \& Piano Clarke, 2017). In this case, the content of the national curriculums informed the teacher survey. As Creswell and Creswell (2018, p. 14) argued, 'one database could help explain the other database, and one database could explore different types of questions than the other database'. In our study, analyzing both the curriculums and the survey provided us with valuable data to answer the research questions. To study the content of curriculums drawn up for ECTE in Denmark and Norway, we first conducted a document analysis of the national curriculums for the ECTE bachelor program in the two countries, after which we compared our findings. The most important benefit of international comparisons is the 'variety of manifestations which makes hidden national characteristics visible' (Blömeke \& Paine, 2008), which sheds new light on the system in each country. Comparing the ECTE programs across two countries with very similar ideals made it possible to reveal differences that were invisible on the surface, thus leading to a deeper knowledge of the national cultural values. According to Blömeke and Paine (2008), adopting a cross-country perspective in research allows wider perspectives to emerge about the typical and atypical aspects of education in each country.

The second method used, the survey, was developed partly based on the results of the document analysis. It was distributed to all the early childhood student teachers in the study at the end of their education at three separately located departments of one Danish University College and three Norwegian University Colleges. As the three Danish departments had recently been merged into one University College, the participating Danish students had followed local interpretations and the educational organization of the Danish curriculum. The questions in the survey were developed by both the Danish and Norwegian researchers, with several drafts going back and forth between the two countries. The survey consisted of questions related to key areas of children's learning and development. It was delivered on paper to the student teachers in their native language, either Danish or Norwegian.

\section{The Document Analysis}

The research question for this analysis was: What are the goals concerning children's language learning and early literacy in the national curriculums of the Danish and Norwegian ECTE? More specifically, our analysis was inspired by a qualitative content analysis, which, according to Grønmo (2017), builds on a systematic study of documents, where the aim is to categorize the content and register data relevant to the research question. The documents analyzed in this study are the national curriculums of the two countries.

The overall aim of the content analysis was to investigate how children's language learning and early literacy were described in the national curriculums for ECTE. We read through the curriculums three times. The first time we looked at the content, we identified specific words like 'language learning/development', how they related to conversations and reading books, and how frequently the words occurred in the documents. Our second reading focussed on the concepts described in the content. On our third reading of the documents, analysis focussed on where and how the three types of knowledge (knowing what, knowing how, and knowing why) occurred in the texts (Shulman, 2004). The analytic process is presented in Table 1, below. 
Table 1. The Analytical Process

\begin{tabular}{|c|c|c|c|}
\hline & Purpose & Analytic Strategies & Research Question \\
\hline Reading 1 & $\begin{array}{l}\text { Identify the content regarding } \\
\text { early literacy in the national } \\
\text { curriculums. }\end{array}$ & $\begin{array}{l}\text { Determine the frequencies } \\
\text { of keywords: language } \\
\text { learning/development, } \\
\text { oral/written language. }\end{array}$ & $\begin{array}{l}\text { What concepts emerge about } \\
\text { children's language learning } \\
\text { and early literacy? }\end{array}$ \\
\hline Reading 2 & $\begin{array}{l}\text { Through the concepts revealed } \\
\text { in the first reading, identify } \\
\text { how the national curriculums } \\
\text { construe early literacy. }\end{array}$ & $\begin{array}{l}\text { Discover the words that are } \\
\text { most frequently connected } \\
\text { to the topic of language } \\
\text { learning and early literacy. }\end{array}$ & $\begin{array}{l}\text { How are language learning } \\
\text { and early literacy described } \\
\text { in the national curriculums? }\end{array}$ \\
\hline Reading 3 & $\begin{array}{l}\text { Discuss the construction of } \\
\text { content related to what, how, } \\
\text { and why. }\end{array}$ & $\begin{array}{l}\text { Compare the scope of the } \\
\text { content related to what, } \\
\text { how, and why. }\end{array}$ & $\begin{array}{l}\text { Which topics are prioritized } \\
\text { highest in the national } \\
\text { curriculums? }\end{array}$ \\
\hline
\end{tabular}

The first part of the analysis was to study the national curriculums of each country to determine whether and where there are differences and similarities in content and goals. Our analysis of the national curricula shows that both regard knowledge of children's language learning and children's literature as very important. Both countries also consider pedagogical competence to be a vital component of their education programs. Many of the knowledge areas mentioned in the Norwegian and Danish National curricula are much alike, with only minor differences. In addition, both countries believe social pedagogical discourse to be of importance, see Table 2 .

Table 2. Knowledge Areas

\begin{tabular}{|l|l|l|l|l|l|l|}
\hline Norway & $\begin{array}{l}\text { Children's } \\
\text { development, } \\
\text { play, and } \\
\text { learning }\end{array}$ & $\begin{array}{l}\text { Society, } \\
\text { religion, } \\
\text { spirituality, } \\
\text { and ethics }\end{array}$ & $\begin{array}{l}\text { Language, } \\
\text { text, and } \\
\text { mathematics }\end{array}$ & $\begin{array}{l}\text { Art, } \\
\text { creativity, } \\
\text { and } \\
\text { culture }\end{array}$ & $\begin{array}{l}\text { Nature, } \\
\text { health, and } \\
\text { movement }\end{array}$ & $\begin{array}{l}\text { Leadership, } \\
\text { cooperation, and } \\
\text { developmental } \\
\text { work }\end{array}$ \\
\hline Denmark & Pedagogy & $\begin{array}{l}\text { Danish, } \\
\text { culture, } \\
\text { and } \\
\text { communi- } \\
\text { cation }\end{array}$ & $\begin{array}{l}\text { Individual, } \\
\text { institution, } \\
\text { and society }\end{array}$ & $\begin{array}{l}\text { Health, } \\
\text { body, and } \\
\text { movement }\end{array}$ & $\begin{array}{l}\text { Expressions, } \\
\text { music, and } \\
\text { drama }\end{array}$ & $\begin{array}{l}\text { Workshop, nature, } \\
\text { and technique }\end{array}$ \\
\hline
\end{tabular}

There are six knowledge areas in the Norwegian National Curriculum, two of which are relevant for this study. The first targets Children's development, play, and learning, and the second address Language, text, and mathematics. In the latter knowledge area, student teachers are expected to gain a wider knowledge of children's language development and to acquire basic skills in teaching children to read, write, and develop mathematical skills. Student teachers are expected to learn about children's oral and written language and language development, including multilingual and multicultural perspectives. Furthermore, student teachers have to demonstrate an awareness of the importance of play for children's language development.

The Danish National Curriculum also encompasses six knowledge areas. The first area relevant to this study targets Pedagogy and the second is entitled Danish, Culture, and Communication. Danish student teachers are expected to acquire knowledge about children's language development and language stimulation, including the importance of written language. Furthermore, they must learn how to support children's general communication and language skills development. Although both national curriculums draw upon broad concepts of children's language learning and early literacy—including body language, play, and culture — here we see 
a difference between the two curriculums. While the Norwegian National Curriculum presents the importance of play in language learning, the Danish National Curriculum considers stimulating children's language to be more important.

The main result when analyzing to address the first research question is that both curricula emphasize the importance of play in connection with children's language learning. An examination of the content of the knowledge areas and learning outcomes descriptions of the two curriculums reveals more focus on language learning and literacy in the Norwegian National Curriculum compared to the Danish National Curriculum. Although ECTE is being influenced by political trends that consider learning and education, including early literacy, to be affirmative action, the social pedagogical approach to early childhood education remains the dominant ECTE paradigm in both countries (Bennet, 2010). This includes a child-centered approach to language learning and early literacy. At the same time, there are significant differences in the organization of the two ECTE programs. Concerning academic education and practice placement, the Norwegian ECTE only qualifies graduates for employment in early childhood institutions, while the Danish ECTE is part of a more general pedagogical qualification that gives access to employment in diverse areas of social pedagogical work with children and young people in care and special needs institutions.

In looking at the two countries' national plans for ECTE and applying the 'what, why, and how elements', we found that the 'what element' was quite similar in both programs, the 'why element' was somewhat vaguer in the Danish Curriculum than in the Norwegian Curriculum, and the 'how element' was explicitly stated in both national curriculums. Unlike Norway, the documents in the Danish curriculum contain no references to 'why' the student teachers must acquire this type of knowledge, nor are there any references to the research used as background in developing the National Curriculum.

\section{The Survey}

The second research question is, How satisfied are Danish and Norwegian student teachers with their own subjective learning outcomes related to children's language learning and early literacy? Fifty-eight questions were posed to the student teachers, asking them to evaluate their subjective learning outcomes in key areas of children's learning and development. To ensure that student teachers in both countries were given a survey in their own language, the questionnaire was translated and piloted in each country separately.

The questions were designed to distinguish between learning outcomes in the three types of knowledge: 'knowing what', 'knowing how', and 'knowing why' (Shulman, 2004). Several studies have shown that student teachers adopt different approaches to learning, ranging from approaches resulting in surface learning to those that promote deeper learning. This of course raises the classic question of how to ensure that students engage in the latter (Darling-Hammond et al., 2005; Marton \& Säljö, 1976). With this in mind, we expect that more student teachers would report a positive learning outcome in factual knowledge, and a poorer learning outcome in procedural and meta-knowledge.

The rating scale categories used were: 'to a small extent', 'to some extent', 'to a large extent', and 'to a very large extent'. It is important to stress here that, since the students reported their 
subjective learning outcomes on each question, we have no objective, or direct, measurement of the level of student teachers' knowledge and competence.

For each question/variable, respondents indicated how satisfied they were with that learning outcome, choosing from 'to a small extent', 'to some extent', 'to a large extent', and 'to a very large extent'. A four-point scale pushed respondents to consider the statement and reduced the possibility of respondents taking 'the easy way out' by choosing a middle option. On the other hand, there is the risk that respondents decided not to answer a question because of this.

\section{Ethical considerations}

The students received written information about the project. They were informed that participation was voluntary and that they could withdraw from the study without problems at any time. The study was conducted according to the standards of both the Norwegian and the Danish Data Inspectorate (2018).

\section{The sample}

The survey encompassed 199 Norwegian student teachers from three University Colleges and 90 Danish student teachers from three separate campuses at one University College. The survey was distributed on paper and all present student teachers answered the survey questions. The Norwegian student teachers were following a bachelor's degree program following the National ECTC Act of 2013, while the Danish student teachers were the final cohort of students to study following the Danish National Curriculum of 2007. All the student teachers attended the last semester at the end of their study. The majority of the student teachers were women $(86.4 \%)$ and most of the participants were aged between 20 and 29 years $(60.8 \%)$. As many as $72.1 \%$ of the participants had worked in a preschool before starting their bachelor's education.

\section{The data collection process}

The survey was conducted by the researchers at the end of the students' bachelor's education. The questionnaires were handed out on paper and collected when completed. The questions differentiated between factual knowledge, procedural knowledge, and meta-knowledge (Borko, 2004; Shulman, 2004).

\section{Analysis of the survey data}

In this study, we selected 20 variables related to children's language learning. To determine which of these items were relevant to children's language learning and early literacy, we conducted a reliability analysis concerning those questions in the survey related to language learning, and an item-total correlation (ITC) measured with Cronbach's alpha (alpha). One variable was removed because it had a low ITC and alpha increased when it was excluded

To study the similarities and differences between the Danish and Norwegian student teachers' subjective learning outcomes in the field of children's language learning and early literacy, we used a chi-square test and Cramér's V. We then used an exploratory factor analysis in the identification of four factors: 1) Children's language learning, 2) Language 
interactions, 3) The role of language in learning, and 4) Facilitation of language learning. We made scales based on the sum of the variables in each factor. We used a t-test to compare the two independent samples (the Norwegian and Danish student teachers).

\section{Results of the survey data}

Our analysis of the similarities and differences between the two groups of students showed that the Norwegian students were significantly more satisfied with all their subjective learning outcomes. Four of the variables showed no significant differences between the groups. These variables were concerned with: (1) the facilitation of conversations, (2) why children should learn to solve conflicts through language, (3) how to invite children to talk about their experiences, and (4) the challenges that children with different mother tongues might face. Across these four variables, both groups of students showed that they were only modestly satisfied with their learning outcomes, with most choosing 'to some extent' and 'to a large extent' for these variables. The results of our investigation into the reliability of these factors are presented in Table 3 below.

Table 3. Reliability and Variation of ITC for Each Scale

\begin{tabular}{|l|c|c|c|}
\hline & Alpha & ITC from - to & $\begin{array}{c}\text { Number of } \\
\text { items }\end{array}$ \\
\hline 1. Children's language learning & .89 & $.511-.682$ & 9 \\
\hline 2. Language interactions & .72 & $.628-.657$ & 4 \\
\hline 3. Role of language in learning & .71 & $.421-.736$ & 4 \\
\hline 4. Facilitation of language learning & .77 & $.577-.803$ & 3 \\
\hline
\end{tabular}

Alpha scores were high or satisfactory for all four scales, varying from .71 to .89. The ITC for each scale was also high or acceptable, even for those scales with a low number of items (scales 2, 3, and 4).

The analysis showed that the four factors are clearly distinguished from each other. The first two factors, Children's language learning, and Language interactions included all three knowledge forms: 'what', 'why' and 'how'. The third factor, Role of language in learning, included the knowledge forms 'why' and 'how', while the fourth factor included only the knowledge form 'how' (procedural knowledge). Table 4 shows the results of the factor analysis after two items were excluded.

Table 4. Factor Analysis Based on Varimax Rotation

\begin{tabular}{|l|l|l|l|l|}
\hline Variables & $\begin{array}{l}\text { Children's } \\
\text { language } \\
\text { learning }\end{array}$ & $\begin{array}{l}\text { Language } \\
\text { interactions }\end{array}$ & $\begin{array}{l}\text { Role of } \\
\text { language } \\
\text { in learning }\end{array}$ & $\begin{array}{l}\text { Facilitation } \\
\text { of language } \\
\text { learning }\end{array}$ \\
\hline $\begin{array}{l}\text { There is a relation between vocabulary and } \\
\text { literacy }\end{array}$ & .746 & & \\
\hline How to support toddlers' language learning & .703 & & & \\
\hline $\begin{array}{l}\text { How children learn words for concrete objects, } \\
\text { activities }\end{array}$ & .682 & & & \\
\hline Children's vocabulary is essential to literacy & .677 & & & \\
\hline Teachers shall support reading and writing & .672 & & & \\
\hline Why promote children's use of spoken language & .651 & & & \\
\hline Knowledge of the general language development & .601 & & & \\
\hline
\end{tabular}




\begin{tabular}{|c|c|c|c|c|}
\hline Variables & $\begin{array}{l}\text { Children's } \\
\text { language } \\
\text { learning }\end{array}$ & $\begin{array}{l}\text { Language } \\
\text { interactions }\end{array}$ & $\begin{array}{l}\text { Role of } \\
\text { language } \\
\text { in learning }\end{array}$ & $\begin{array}{l}\text { Facilitation } \\
\text { of language } \\
\text { learning }\end{array}$ \\
\hline Why encourage children's use of language & .562 & & & \\
\hline $\begin{array}{l}\text { The use of dialogue about topics when you read } \\
\text { books }\end{array}$ & .522 & & & \\
\hline $\begin{array}{l}\text { Challenges second language learners meet in peer } \\
\text { interactions }\end{array}$ & & .657 & & \\
\hline $\begin{array}{l}\text { Why encourage children to use language to solve } \\
\text { conflicts }\end{array}$ & & .651 & & \\
\hline $\begin{array}{l}\text { How to invite children to narrate, describe, and so } \\
\text { on }\end{array}$ & & .649 & & \\
\hline $\begin{array}{l}\text { Teachers must use words children know to } \\
\text { promote language }\end{array}$ & & .628 & & \\
\hline $\begin{array}{l}\text { Why there is a connection between language and } \\
\text { cognition }\end{array}$ & & & .736 & \\
\hline $\begin{array}{l}\text { How to promote cognitive development in } \\
\text { children }\end{array}$ & & & .726 & \\
\hline $\begin{array}{l}\text { Why language competence and learning are } \\
\text { connected }\end{array}$ & & & .650 & \\
\hline $\begin{array}{l}\text { How children acquire knowledge in different } \\
\text { areas }\end{array}$ & & & .421 & \\
\hline $\begin{array}{l}\text { How to invite children to participate in language } \\
\text { interactions }\end{array}$ & & & & .803 \\
\hline How to facilitate conversations between children & & & & .794 \\
\hline How to support children's learning of words & & & & .577 \\
\hline
\end{tabular}

Note. Figures in italics show to which scale the variables belong.

The comparison between the Norwegian and Danish student teachers is based on an independent sample test, see Table 5 below.

Table 5. Differences Between the Norwegian and Danish Students on the Four Factors

\begin{tabular}{|l|c|c|c|c|c|c|c|c|}
\hline & \multicolumn{3}{|c|}{ Norway } & \multicolumn{3}{c|}{ Denmark } & & \\
\hline & Mean & SD & $\mathrm{N}$ & Mean & SD & $\mathrm{N}$ & t-value & sig \\
\hline 1. Children's language learning & 29.83 & 4.26 & 197 & 23.21 & 5.10 & 86 & 11.30 & .000 \\
\hline 2. Language interactions & 11.77 & 2.42 & 199 & 10.93 & 2.50 & 88 & 2.67 & .008 \\
\hline 3. Role of language in learning & 12.16 & 2.10 & 196 & 10.71 & 2.50 & 90 & 4.76 & .000 \\
\hline 4. Facilitation of language learning & 8.83 & 1.10 & 198 & 7.61 & 2.01 & 90 & 4.83 & .000 \\
\hline
\end{tabular}

The t-test revealed clear, significant differences in student teachers' evaluations of their subjective learning outcomes in the two countries. The survey showed that the Norwegian student teachers were more satisfied with their subjective learning outcomes on all four factors. The difference, however, was most clearly expressed in the first factor, Children's language learning. However, both the Danish and Norwegian student teachers were more satisfied with what they had learned than how they might use their theoretical knowledge in pedagogical work. This may indicate a weak coherence between theory and practice.

\section{Discussion}

The Norwegian student teachers reported significantly higher satisfaction with their learning outcomes on all four factors of children's language learning and early literacy than the Danish student teachers (Table 5). This difference cannot be attributed to either the content of the 
curriculums or the intentions articulated in the Danish National Curriculum as compared to the Norwegian National Curriculum, because they are very similar; both curriculums consider knowledge within the field of children's language learning and children's literature to be very important. One explanation for the differences may be related to the student teachers' intentions in choosing their course of study since in Denmark the ECTE is only one subject in a broader, more general program. Another explanation might be that the importance of research-based education is stated explicitly in the Norwegian National Curriculum, while the 2007 Danish National Curriculum does not highlight this to the same extent. Yet another possible explanation for the variation in subjective learning outcomes might be due to differences in the coherence between theory and practice in each of the programs run in the two countries and their teaching institutions. Finally, it might partly be explained by the fact that the Norwegian student teachers had the benefit of educational supervision in their practice placement periods. The results of the survey may further be related to the fact that these possible interpretations may be connected and mutually influence each other.

At a more detailed level, there were variations in how much time students spent studying at the University Colleges in terms of the ECTS credits awarded for college time and practice placement time. A comparison of the student teachers' practice placement periods in the two countries reveals significant differences, which are due to the different roles played by these work periods in the overall curriculum. While the Danish education program assigns a total of 210 ECTS credits, 60 ECTS credits are deducted for the two placement periods. This leaves 150 ECTS credits for the Danish students, compared to 180 ECTS credits for the Norwegian students. One could argue that there are only minor differences in the knowledge areas themselves, specifically in the areas of language learning and literacy. However, the Danish knowledge area covers a much wider range of subjects, while the Norwegian curriculum focuses only on ECEC. In addition, the fact that the Norwegian National Curriculum fully integrates practice placement as a part of its degree program and the knowledge areas can also be a way of highlighting the importance of a theory-based practice placement period.

The Danish way of organizing the bachelor program in education differs from the Norwegian Curriculum in that it detaches the practice placement periods from the students' studies at the university college. The student teachers lose academic study time because the university college is not involved in their practice placement periods. This way of organizing practice placement and supervision divides the educational responsibility for the curriculum and the degree, a situation that might harm the Danish students' performance because of the program's lack of coherence between theory and practice. According to Smeby and Heggen (2014), a strong, coherent link between theoretical knowledge and practice is vital. The lack of a close link between these knowledge areas can probably explain some of the variations in the subjective learning outcomes between the Danish and Norwegian student teachers. According to Høydalsvik (2017), who has documented the importance of coherence between theoretical knowledge and practice in ECTE, this is also a challenge in the Norwegian ECTE.

A Nordic mapping of ECEC research shows that Denmark is falling behind the other Nordic countries when it comes to research in ECEC (Bondebjerg et al., 2018). A mapping of Scandinavian research in 2016 revealed that Norway produced $40 \%$ of the total research, while Denmark produced only 17\%. Another remarkable fact is that, during the last 10 years, Denmark's relative share of ECEC research within the Nordic countries dropped from $33 \%$ in 
2006 to $17 \%$ in 2016 (Bondebjerg et al., 2018). This indicates differences in Danish and Norwegian researchers' access to private and public research funding. In addition, it is reasonable to conclude that, compared to their Danish counterparts, teacher educators in Norway conduct more research and are given significantly more access to national research that they can use in the classroom. This could have an impact on the quality of ECTE and result in differences in Danish and Norwegian student teachers' evaluations of their subjective learning outcomes.

Overall, our analysis of the survey demonstrated high levels of satisfaction with subjective learning outcomes concerning the topic of language learning. Although the Norwegian student teachers were more satisfied with their learning outcomes generally, the Danish students were still reasonably satisfied, choosing the second-highest response options for 13 of the 20 questions. In the Norwegian National Curriculum, the student teachers' learning outcomes are formulated more explicitly and are directed towards work with children in ECEC. The Danish National Curriculum focuses more generally on 'users' and is not as specifically directed towards working with children in ECEC. In this study, the 'how element' (procedural knowledge), which is related to language learning, showed a surprising difference between the Danish and Norwegian student teachers. The fact that the Danish student teachers gain more practical experience through their education program does not have a significant impact on their subjective evaluations of procedural knowledge.

One recent study contained quotes from teacher educators in Norway in which they stated that they had insufficient time to provide student teachers with procedural knowledge in language learning and early literacy and that they expected student teachers to acquire procedural knowledge during their practice placement periods (Vatne \& Gjems, 2017). This might indicate that procedural knowledge is a kind of knowledge the student teachers do acquire through their teaching practice.

\section{Methodological Considerations}

The strengths of the study lie in the fact that we together analyzed and discussed the Danish and Norwegian curriculums using data obtained from surveys conducted in both countries. However, we also want to emphasize that the study has some limitations. First, when we discuss the students' self-reports in light of the national curriculums, we are fully aware that the road from curriculum to implementation in education is a limited perspective. However, we find this an interesting perspective to discuss. Second, the students' self-reporting is a limitation of the study. Thus, to provide more rich and varied data, future studies should also include interviews with students, teacher educators, and practical training teachers in ECEC from both countries. Moreover, the approach highlights some similarities and equalities in the national curriculums of Danish and Norwegian ECTE and addresses Danish and Norwegian student teachers' high satisfaction levels regarding their own subjective learning outcomes related to children's language learning and early literacy. 


\section{Conclusions}

One significant difference between the Danish and Norwegian National Curriculums concerning the goals of ECTE is how each view practice placement as part of the education. In Norway, there is a strong emphasis on practice placement as an integrated part of the curriculum. This provides Norwegian students with the opportunity to receive guidance and supervision from their university teachers during their practice placement period. This can also promote coherence between what they have learned in theory and what they learn through practice placement. The Norwegian way of planning and implementing a professional education suggests that they view education as being mainly the responsibility of the university/university college, whereas responsibility in the Danish system of professional education is divided between the university college and the early childhood labor market. In addition, our content analysis revealed significant differences in the content that focusses on ECEC. Not only does the Danish National Curriculum present a broad focus on development, learning, and language, and preparing students to work with adults as well as children, but Danish student teachers spend less time studying ECEC compared to Norwegian student teachers.

This study reveals that Norwegian student teachers evaluate their subjective learning outcomes in the fields of language learning and early literacy more highly than do Danish student teachers. Our research points to the fact that the breadth of subjects in the Danish ECTE bachelor program tends to result in lower subjective learning outcomes in these knowledge areas compared to the Norwegian ECTE. This fact begs the question as to whether Norwegian early childhood teachers, compared to their Danish colleagues, perform and support children better in early childhood education. To learn what factors can enhance the quality of student teachers' learning outcomes to produce more professional teachers, and to ensure a high level of quality in ECTE and ECEC, it is important to carry out further studies that address Nordic differences and similarities in the field of early literacy in ECEC.

\section{References}

August, D., Carlo, M., Dressler, C., \& Snow, C. (2005). The critical role of vocabulary development for English language learners. Learning Disabilities Research and Practice, 20(1), 50-57. https://doi.org/10.1111/j.1540-5826.2005.00120.x

Aukrust, V. G., \& Rydland, V. (2009). Barnehagens kvalitet og skolefaglig læring: en kunnskapsoversikt. Norsk Pedagogisk Tidsskrift, 90(3), 178- 187.

Barnett, S. ( 2003). Better teachers, better preschools: Student achievement linked to teacher qualifications. NIEER Preschool Policy Matters, Issue 2. National Institute for Early Education Research (NIEER), Rutgers, The State University.

Barton, D. (2007). Literacy. Blackwell Publishing.

Bennet, J. (2010). Pedagogy in early childhood services with special reference to Nordic approaches. Psychological Science and Education, 15(3), 16-21. https://psyjournals.ru/en/psyedu/2010/n3/Bennet.shtml

Blömeke, S., Felbrich, A., Müller, G., \& Lehmann, R. (2008). Effectiveness of teacher education - State of research, measurement issues and consequences for future studies. ZDM Mathematics Education, 40, 719-734. https://doi.org/10.1007/s11858-008-0096-X

Blömeke, S., \& Paine, L. (2008). Getting the fish out of the water: Considering benefits and problems of doing research on teacher education at an international level. Teaching and Teacher Education, 24(4), $2027-$ 2037. https://doi.org/10.1016/j.tate.2008.05.006 
Bondebjerg, A., Jessen, A., Jusufbegovic,L., \& Vestergaard, S. (2018). Forskningskortlægning og -vurdering af skandinavisk dagtilbudsforskning for 0-6-årige i året 2016. Dansk Clearinghouse for Uddannelsesforskning, DPU, Aarhus Universitet.

Borko, H. (2004). Professional development and teacher learning: Mapping the terrain. Educational Researcher, 33(8), 1-49. https://doi.org/10.3102/0013189x033008003

Creswell, J. W., \& Creswell, J. D. (2018). Research design: Qualitative, quantitative, and mixed methods approaches. Sage Publications, Inc.

Creswell, J., \& Piano Clarke, V. (2017). Designing and conduction mixed method research ( ${ }^{\text {rd }}$ ed.). Sage.

Cunningham, A., Zibulsky, J., Stanovich, K., \& Stanovich, P. (2009). How teachers would spend their time teaching language arts. The mismatch between self-reported and best practices. Journal of Learning Disabilities, 42(5), 418. 430. https://doi.org/10.1177/0022219409339063

Darling-Hammond, L., Hammerness, K., Grossman, P., Rust, F., \& Shulman, L. (2005). The design of teacher education programs. In L. Darling-Hammond \& J. Bransford (Eds.), Preparing teachers for a changing world. What teachers should learn and be able to do (pp. 390-441). Jossy Bass, Whiley.

Dickinson, D., \& Porche, M. (2011). Relation between language experiences in preschool classrooms and children's kindergarten and fourth-grade language and reading abilities. Child Development, 82(3), 870886. https://doi.org/10.1111/j.1467-8624.2011.01576.x

Dickinson, D., McCabe, A., Anastasopolulos, L., Peisner-Feinberg, E., \& Poe, M. (2003). The comprehensive language approach to early literacy: The interrelationships among vocabulary, phonological sensitivity, and print knowledge among preschool-aged children. Journal of Educational Psychology, 95(3), 465481. https://doi.org/10.1037/0022-0663.95.3.465

Early, D. M., Bryant, D. M., Pianta, R. C., Clifford, R. M., Burchinal, M.B., Ritchie, S., Howes, C. \& Barbarin, O. (2006). Are teacher education, major, and credentials related to classroom quality and children's academic gains in pre-kindergarten? Early Childhood Research Quarterly, 21(2), 174-195. https://doi.org/10.1016/j.ecresq.2006.04.004

Early, D. M., Maxwell, K. L., Burchinal, M., Alva, S., Bender, R. H., Bryant, D., Cai, K., Clifford, R. M., Ebanks, C., Griffin, J. A., Henry, G. T., Howes, C., Iriondo-Perez, J., Jeon, H., Mashburn, A. J., PeisnerFeinberg, E., Pianta, R. C., Vandergrift, N., \& Zill, N. (2007). Teachers’ education, classroom quality, and young children's academic skills: Results from seven studies of preschool programs. Child Development, 78(2), 558-580. https://doi.org/10.1111/j.1467-8624.2007.01014.x

Einarsdottir, J., \& Wagner, J. (2006). The Nordic childhoods and early education: Philosophy, research, policy and practice in Denmark, Finland, Iceland, Norway and Sweden. Information Age Publishing.

Einarsdottir, J. (2013). Early childhood teacher education in the Nordic countries. European Early Childhood Education Research Journal, 21(3), 307-310. https://doi.org/10.1080/1350293x.2013.814321

Gjems, L. \& Sheridan, S. (2015). Early literacy in Norwegian and Swedish preschool teacher education. Psychology in Russia: State of the Art, 8(2), 1-14. https://doi.org/10.11621/pir.2015.0201

Grossman, P., Hammerness, K., McDonald, M., \& Ronfeldt, M. (2008). Constructing coherence - Structural predictors of perceptions of coherence in NYC teacher education programs. Journal of Teacher Education, 59(4), 273-287. https://doi.org/10.1177/0022487108322127

Grønmo, S. (2017). Samfunnsvitenskapelige metoder, 2. opplag. Fagbokforlaget.

Hattie, J. (2009). Visible learning: A synthesis of over 800 meta-analyses relating to achievement. Routledge.

Hjetland, H. N., Brinchmann, E., Scherer, R., Melby-Lervåg, M. (2017). Preschool predictors of later reading comprehension ability: A systematic review. Campbell Systematic Reviews, 13(1), 1-155. https://doi.org/10.4073/csr.2017.14

Høydalsvik, T. (2017). Co-operation is not enough: Teacher educators as curriculum developers in times of change. International Journal of Higher Education, 3(2), 76-87. https://doi.org/10.5430/ijhe.v6n5p76

Manning, M., Garvis, S., Fleming, C., \& Wong, G. (2017). The relationship between teacher qualification and the quality of the early childhood care and learning environment. Campbell Systematic Reviews, 13(1), 182. https://doi.org/10.4073/csr.2017.1

Marton, F., \& Säljö, R. (1976). On qualitative differences in learning: I - Outcome and process. British Journal of Educational Psychology, 46(1), 4-11. https://doi.org/10.1111/j.2044-8279.1976.tb02980.x

Ministry of Education and Research. (2012). National Guidelines for Preschool Teacher Education. Ministry of Education and Research. 
The Ministry of Higher Education and Science. (2007). The Danish Act. The National Curriculum.

Ministry of Science, Technology and Innovation (2005). A Framework for Qualifications of the European Higher Education Area. Bologna Working Group on Qualifications Frameworks. Grefta Tryk.

Nelson, K. (2009). External representations critical to human intelligence. In C. Andersen, M. Echeverria, \& N. Scheuer (Eds.), Representational systems and practices as learning tools (pp. 297-313). Sense Publisher.

Neuman, S., \& Cunningham, L. (2009). The impact of professional development and coaching on early language and literacy instructional practices. American Educational Research Journal, 46(2), 532-566. http://dx.doi.org/10.3102/0002831208328088

Neuman, S., \& Marulis, L. (2010). The effects of vocabulary intervention on young children's word learning: A meta-analysis. Review of Educational Research, 80(3), 300-335.

https://doi.org/10.3102/0034654310377087

Ohlson, S. (2011). Deep learning: How the mind overrides experience. Cambridge University Press.

Polat, N. (2010). Pedagogical treatment and change in preservice teacher beliefs: An experimental study. International Journal of Educational Research, 49, 195-209. https://doi.org/10.1016/j.ijer.2011.02.003

Report of the Working Group on Early Childhood Education and Care under the auspices of the European Commission. (2014). Key principles of a quality framework. Proposal for key principles of a quality framework for early childhood education and care. https://ec.europa.eu/assets/eac/education/policy/strategic-framework/archive/documents/ecec-qualityframework en.pdf

Roth, Ann-Christine. (2014). Nordic comparative analysis of guidelines for quality and content in early childhood education. Nordic Early Childhood Education Research Journal, 8(1), 1-35. https://doi.org/10.7577/nbf.693

Sandvik, J., van Daal, V., \& Adèr, H. (2014). Emergent literacy: Preschool teachers' beliefs and practices. Journal of Early Childhood Literacy, 14(1), 28-52. https://doi.org/10.1177/1468798413478026

Sheridan, S., Williams, P., Sandberg, A., \& Vourinen, T. (2011). Preschool teaching in Sweden - a professional change. Educational Researcher, 54(4), 415-437. https://doi.org/10.1080/00131881.2011.625153

Shulman, L. (2004). Those who understand: Knowledge growth in teaching. In Shulman, L. \& Wilson, S. (Eds.), The wisdom of practice: Essays on teaching, learning, and learning to teach. Jossey-Bass.

Smeby, J.-C., \& Heggen, K. (2014). Coherence and the development of professional knowledge and skills. Journal of Education and Work, 27(1), 71-91. https://doi.org/10.1080/13639080.2012.718749

Snow, C. (2000). On language and literacy development. Early Childhood Today, 15(2), 1-46.

Snow, C., Tabors, P., \& Dickinson, D. (2001). Language development in the preschool years. In D. Dickinson \& P. Tabors (Eds.), Beginning literacy with language (pp. 1-27). Paul H. Brookes Publishing Co.

Sylva, K., Melhuish, E., Sammons, P., Siraj-Blatchford, I., \& Taggart, B. (2010). Early childhood matters: Evidence from the effective pre-school and primary education project. Routledge.

UNESCO. (2013). Global media and information literacy assessment framework: Country readiness and competencies. The United Nations Educational, Scientific and Cultural Organization (UNESCO).

Vatne, B. \& Gjems, L. (2017). Preschool teacher educators' conceptions about teaching early literacy to future preschool teachers. Journal of Early Childhood Education Research, 6(1), 148-162.

Zeichner, K. (2006). Studying teacher education programs: Enriching and enlarging the inquiry. In C. Clifton \& R. Serlin (Eds.), The Sage handbook for research in education: Engaging ideas and enriching inquiry (pp. 79-94). Sage Publications Inc. http://dx.doi.org/10.4135/9781412976039.n5 